\title{
How Teaching Affects Student Attitudes towards the Environment and Sustainability in Higher Education: An Instructors' Perspective
}

\author{
By Anastasia Misseyanni ${ }^{1}$, Christina Marouli ${ }^{1}$, Paraskevi Papadopoulou ${ }^{1}$
}

\begin{abstract}
In the rapidly changing, 21 st century globalized world, with increasing environmental pressures and challenges, education for the environment and sustainability is a priority at all levels; from kindergarten to higher education. It is the education that will create the environmentally aware and socially responsible individuals, capable of addressing existing and future environmental challenges. Courses on the environment and/or sustainability are now an essential element of all Higher Education Institutions with a sustainability vision. But, does teaching about the environment and sustainability lead to a change in student attitudes? What teaching and learning methods seem to have a more significant effect on attitudes and behaviors and what are the challenges for instructors? In this study, instructors reflect on which educational methods seem most effective in promoting change in student attitudes and behaviors towards the environment and sustainability. This reflection is based on instructor experiences from selected courses or course activities (learning objects) and it focuses on the goals, teaching methods and effect on student learning and attitudes; changes in student attitudes in the course of the last years are also discussed. Suggestions are offered and implications for higher education institutions are outlined.
\end{abstract}

Keywords: education for the environment, education for sustainability, higher education, active learning, student behaviors, emotional engagement

\section{Introduction}

The purpose of education has been extensively discussed, and different views and theories have been expressed. Education can have as main purpose the unidirectional transmission of facts, information, skills and values from teacher to learner. Such transmissive education, characterized by an instructor-centered approach to teaching, can prepare students well to accept their role in society and the workforce and can facilitate the "integration of the younger generation into the logic of the present system" (Shaull, 1970:15), thus leading to social reproduction. On the other hand, education can also become "the "practice of freedom", the means by which men and women deal critically and creatively with reality and discover how to participate in the transformation of their world." (Shaull, 1970:15); with knowledge being cocreated within a social context, by transacting with prior knowledge, the curriculum and other learners. Such an educational approach, characterized by a more student-centered teaching, is capable of creating educated citizens who will become active participants in ongoing decision-making processes within their communities; it is the kind of education that will lead to social transformation (Jickling \& Wals, 2008).

How can education respond to contemporary global challenges such as environmental degradation, climate change, poverty, population growth, social inequality? What type of 
education is needed to promote sustainable development and the much-needed change in attitudes and behaviors that is required to achieve its goals? These are the main general questions this study aims to address based on the long-term and diverse teaching experiences of the authors.

\section{Attitudes of Undergraduate Students towards the Environment and Sustainability}

A change in people's attitudes and behaviors is essential for sustainable development. Environmental Education (EE) and Education for Sustainability (EFS) (see section 3) have the potential to cultivate pro-environmental attitudes and behaviors. It should be noted that change in behaviors does not necessarily mean change in attitudes (Eilam and Trop, 2012). According to Dobson (2007), fiscal incentives may lead to change in behaviors; but attendance to changing attitudes by promoting environmental and ecological citizenship in high school curricula may produce more long-lasting effects on behaviors. Neither does change in attitudes automatically lead to behavioral change. Some of the factors that affect student attitudes and behaviors towards the environment and sustainability include knowledge and level of awareness (Sahini \& Erkal, 2017), as well as economic issues (Rosentrater \& Burke, 2018). However, individual motivation is not enough; the space and time structures in which people live affect their behavioral choices as well, as Giddens' theory of structuration highlights, too (Cassell, 1993; Lorenzoni, Nicholson-Cole \& Whitmarsh, 2007; Marouli \& Duroy, 2014; Račinska, Barratt \& Marouli, 2015).

This study focuses on attitudes of undergraduate students in higher education (HE). Important trends that characterize higher education today include globalization, increasing student mobility and internationalization, increasing dependence on ICTs, interdisciplinarity, online learning, active learning, personalized learning, connection with society and industry, service learning, community-based learning, emphasis on sustainability (Papadopoulou, Marouli, Misseyanni \& Lytras, 2017). In this changing HE picture, education for sustainability can take place in different ways. One way is through the curriculum, which may include courses with environmental and sustainability components, as well as undergraduate and graduate programs in environmental studies and sustainability. A second way is through extra-curricular activities: students get involved with student organizations and other institutional entities (e.g. sustainability centers) and initiatives that raise awareness of environmental issues and promote sustainability. Both approaches (curricular and extra-curricular) can stimulate increased levels of care for the environment and pro-environmental attitudes and behaviors (Pizmony-Levy \& Michel, 2018). Among the numerous studies of student perception towards the environment and sustainability in HE, the study of Ull, Martinez-Agut, Pinero \& Aznar-Minguet (2014) showed positive student attitudes towards introduction of sustainability issues in teaching.

\section{Education for Sustainability, Active Learning and Use of ICTs}

Environmental Education (EE) is a concept that arose in the 1970s (UNESCO, 1975; UNESCO, 1977) as a response to increasing social awareness of the significance of 
environmental issues and their inter-relationship with human activities. EE helps individuals develop a deeper understanding of environmental issues and acquire the knowledge and skills to make informed and responsible decisions. It aims to provide knowledge about how ecosystems work, emphasizes "outdoors education", uses emotion as a fundamental stimulus and has been characterized by interdisciplinary collaboration (Marouli, Misseyanni, Papadopoulou \& Lytras, 2018). Agenda 21 (UNESCO, 1992) was the first international document that identified education as an important tool to promote sustainable development. Education for Sustainability (EFS)/Education for Sustainable Development (ESD) are terms that describe education that promotes sustainable development and improves the capacity of people to address environmental and development issues. UNESCO highlights the importance of integrative approaches in EFS/ESD, connecting environmental, social, economic and cultural aspects. EFS/ESD emphasizes "compromise solutions" and is more human-centered, with social and economic aspects of sustainability sometimes gaining more attention than environmental aspects (Marouli, Misseyanni, Papadopoulou \& Lytras, 2018). Although the transition from $\mathrm{EE}$ to $\mathrm{EFS} / \mathrm{ESD}$ received variable responses within the environmental education community -both positive and negative- (Hesselink, van Kempen \& Wals, 2000), EFS/ESD is now more widely seen as a broader, improved version of $\mathrm{EE}$, and this can also be seen at the level of national policy in many countries (Jickling \& Wals, 2008).

So, what teaching methods promote more student engagement in the learning process and seem to have an effect on attitudes and behaviors? What are the challenges for instructors who aim to teach for pro-environmental attitudes and behaviors? EE and EFS/ESD have always aimed to develop engaged and critical thinkers as well as active and responsible citizens; and have used active and experiential learning approaches to achieve these goals.

Active learning is the teaching approach that places the student at the center of the learning process. It provides "opportunities for students to meaningfully talk and listen, read and reflect on the content, ideas, issues and concerns of an academic subject" (Meyer and Jones, 1993) and is a key element of "pedagogies of engagement", a term that was introduced to stress the need for modes of teaching and learning that will prepare students for the $21 \mathrm{st}$ century (Edgerton, 2001). Students are engaged at the level of the course with in-class or out-of-class activities (e.g. lab and field work, project-based learning, collaborative learning, online learning), doing things and reflecting on what they do (Bonwell \& Eison, 1991). Active learning in HE may also involve engagement with the community and the society -as part of the curriculum or not-, in the form of service learning and community-based learning (Smith, Sheppard, Johnson \& Johnson, 2005). So, there is a variety of active learning strategies, ranging from more "mainstream" ones emphasizing interactive (usually in-class) instruction, to more "transformative" or empowering ones involving experiential learning, action research approaches that aim to address real community problems. Active learning approaches, especially the most "transformative" variants, empower students and can contribute to the development of critical and creative thinkers and citizens, capable of contributing to social transformation (Marouli, Misseyanni, Papadopoulou \& Lytras, 2018). The authors' previous studies on active learning have examined student and instructor perceptions of the use of different active 
learning approaches in different courses, with focus on STEM disciplines (Misseyanni \& Gastardo, 2017; Misseyanni, Papadopoulou, Marouli \& Lytras, 2018; Misseyanni, Papadopoulou \& Marouli, 2018); these studies have explored, among other, collaborative learning and teaching (Marouli \& Misseyanni, 2017; Misseyanni, Marouli, Papadopoulou \& Lytras, 2017) the use of ICTs and education for sustainability (Marouli, Misseyanni, Papadopoulou \& Lytras, 2016a), game-based learning (Marouli, Misseyanni, Papadopoulou \& Lytras, 2016b), as well as assessment (Papadopoulou, Lytras, Misseyanni and Marouli, 2017).

ICTs play a key role in the modern HE arena and can also prove a powerful tool in supporting Education for Sustainability (Marouli, Misseyanni, Papadopoulou \& Lytras, 2016a). In designing learning activities using ICTs, instructors must address three areas: content, pedagogy, technology. This means that, aside from being "content experts", they should also have good knowledge of pedagogy and technology, thus demonstrating Technological Pedagogical Content Knowledge (TPACK) (Koehler and Mishra, 2009).

The authors' aim in this study was to identify teaching practices that are most effective at cultivating positive student attitudes towards the environment and sustainability, from an instructor-based perspective. And their ultimate goal is to succeed in promoting proenvironmental attitudes and behaviors that are so needed to address increasingly urgent contemporary environmental pressures and challenges.

\section{Methodology}

This work is based on a self-study research approach (Breunig, 2017): three instructors of undergraduate science courses (environmental studies and biology), with long teaching experience, reflected on their teaching. Instructors answered a questionnaire with open-ended questions on: instructors' teaching goals; particular topics (learning objects) related to environment and sustainability taught; learning activities used for the specific learning objects; impact of these activities on learning and student attitudes; and how this impact was evaluated; difficulties/challenges faced; comparison of attitudes of present with past student populations; reflection on effective topics and activities; suggestions for teaching and for $\mathrm{HE}$ administration.

The answers of instructors were informed by student feedback: two instructors also delivered short questionnaires to students of particular classes requesting their reflections on the effectiveness of different teaching methods. Answers were analyzed, similarities and differences were identified and conclusions were drawn. When reference is made to a particular instructor in the Results and Discussion section, the initials of her name will be used (AM, CM and PP).

\section{Results and Discussion}

\subsection{Instructor Teaching Goals - Emotional Engagement as an Aim}

An analysis of instructor answers clearly shows that all three instructors aim at not just transferring knowledge, but also at cultivating critical thinking. They all aim at creating informed citizens who will better address contemporary global challenges and will contribute to a better society. They have as a main teaching goal to raise awareness 
of environmental and sustainability issues. For two of them (who teach mostly environmental courses), this is a major aim. AM aims to make students think and reflect on how they can live more sustainably, while CM aims to bring about change in behaviors in relation to environment and society.

As stated above, Environmental Education has used emotion as a fundamental stimulus. It is an education not just for the environment or on the environment, but also in the environment (Tilbury, 1995); students must "experience" the environment through outdoor activities. To the question whether stimulating emotions is an important aim in teaching, all three instructors agree that emotional engagement may have an impact on the way students feel towards the environment and sustainability. CM considers it essential in teaching and a first step to learning; it cultivates interest in the subject, she reports. PP considers emotional engagement as the "heart of her teaching" and always tries to trigger curiosity and emotions so that students get involved; once they are involved, it gets "easier to teach them difficult concepts". AM says it is not a direct aim for her, but she tries to emotionally engage students because she also feels that this may have an impact on how they feel and act.

\subsection{Topics Taught and Learning Activities Used}

When asked about courses related to the environment and sustainability taught, as well as specific topics and learning outcomes, all three instructors answered that they teach courses with a sustainability component/emphasis. The courses listed are from the environmental sciences/studies (introductory and higher level) and biology fields. Particular topics taught (learning objects) were presented and discussed extensively by two instructors. All topics mentioned had learning outcomes related to sustainability and students' ability to critically discuss environmental and health issues; from biodiversity and ecosystems to climate change, environmental pollution, environmental health and sustainable cities. Examples of topics, learning outcomes, learning activities used and their impact are presented in Table 1.

Table 1: Topics (Learning Objects) related to Environment and Sustainability: Some Examples

\begin{tabular}{|l|l|l|l|}
\hline \multicolumn{2}{|l|}{$\begin{array}{l}\text { Course Content related to Environment and Sustainability: Some Examples } \\
\text { Topic/Learning object }\end{array}$} & Learning Outcome & Learning activity \\
\hline $\begin{array}{l}\text { Teaching about the } \\
\text { Mediterranean Ecosystem } \\
\text { and about ecosystems of the } \\
\text { world (intro) }\end{array}$ & $\begin{array}{l}\text { Discuss ecosystem } \\
\text { characteristics }\end{array}$ & $\begin{array}{l}\text { Field activity where students } \\
\text { make observations and } \\
\text { measurements; Video on } \\
\text { terrestrial biomes }\end{array}$ & $\begin{array}{l}\text { Positive, as judged from } \\
\text { grades in assessments and } \\
\text { student comments }\end{array}$ \\
\hline $\begin{array}{l}\text { Ecological footprint concept } \\
\text { (intro) }\end{array}$ & $\begin{array}{l}\text { Explain and apply concept of } \\
\text { ecological footprint }\end{array}$ & $\begin{array}{l}\text { Students calculate their own } \\
\text { ecological footprint (online } \\
\text { calculator) and reflect on it } \\
\text { through a discussion board }\end{array}$ & $\begin{array}{l}\text { Positive; students report } \\
\text { significant impact on } \\
\text { attitudes, as they are asked } \\
\text { to reflect on their own way of } \\
\text { life. }\end{array}$ \\
\hline $\begin{array}{l}\text { Environmental health issues } \\
\text { (genetics, neurobiology) } \\
\text { (higher level) }\end{array}$ & $\begin{array}{l}\text { Connect disease with } \\
\text { environmental exposures }\end{array}$ & $\begin{array}{l}\text { Short discussions, visuals, } \\
\text { problem solving, group } \\
\text { projects }\end{array}$ & $\begin{array}{l}\text { Positive, as judged from } \\
\text { student feedback }\end{array}$ \\
\hline $\begin{array}{l}\text { Sustainable cities (higher } \\
\text { level) }\end{array}$ & $\begin{array}{l}\text { Critically analyze issues of } \\
\text { sustainable cities }\end{array}$ & $\begin{array}{l}\text { Group project addressing an } \\
\text { issue of concern for the local } \\
\text { community or for students }\end{array}$ & $\begin{array}{l}\text { Positive, as judged from } \\
\text { student feedback }\end{array}$ \\
\hline
\end{tabular}


The most common teaching methods used are summarized in Table 2. They range from simple activities such as in-class discussions and use of audiovisual material to activities that require deeper engagement with course material such as student projects, collaborative projects, literature discussions and role playing referring to simulated real life situations used in higher level courses.

Table 2: Common Teaching Methods Used

\begin{tabular}{|l|l|}
\hline \multicolumn{2}{|l|}{ Common Teaching Methods/Learning Activities Used } \\
\hline All Courses: & $\begin{array}{l}\text { More Advanced Courses (additional } \\
\text { activities): } \\
\text { - in-class discussions }\end{array}$ \\
$\begin{array}{ll}\text { - role playing referring to simulated real life } \\
\text { situations }\end{array}$ \\
- lab and field work & $\begin{array}{l}\text { - student responsibility of a class meeting } \\
\text { and delivery of a lesson }\end{array}$ \\
- quizzes and online discussion boards & $\begin{array}{l}\text { - student project and presentation } \\
\text { - problem solving }\end{array}$ \\
- brainstorming & $\begin{array}{l}\text { group projects that address real } \\
\text { community problems }\end{array}$ \\
- flipped classroom & $\begin{array}{l}\text { internet search for visuals and text on } \\
\text { specific topics }\end{array}$ \\
- case studies & - literature discussion (articles and reports) \\
\hline
\end{tabular}

\subsection{Impact on Learning}

Instructors' reflections on the impact of their teaching on student learning as well as attitudes and behaviors were informed by student performance in the course and comments received in several ways. Table 3 shows the methods used to receive student feedback on the course.

The analysis of instructors' answers reveals that the learning activities used had a positive impact on learning, as judged from grades in assessments (formative and summative), and from electronic student feedback (online evaluations for all courses or student emails). According to AM, engagement matters: the higher the level of engagement with the activity the better the outcome, as testified through a student survey conducted in class and through statistics of the online course management system (see also Misseyanni \& Gastardo, 2019). Students of the Sustainable Cities course have expressed interest in continuing sustainability-related projects after the end of the course, something that shows a longer lasting impact on learning.

The activities that were judged to have a bigger impact on learning were: role playing and experiential exercises in the Environmental Management course; checking waste recycling bins on campus and weighing waste, as part of a waste audit (in an introductory environmental science course); field and lab activities (in all introductory environmental science and biology courses); online quizzes and flipped classroom (in an introductory environmental science course); group projects referring to real community problems (in the Sustainable Cities course).

Table 3: Methods used to receive Student Feedback

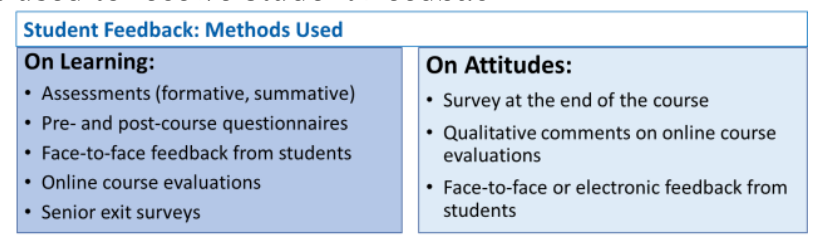




\subsection{Impact on Attitudes and Behaviors}

Concerning the impact of teaching on student attitudes, instructors report that some students were more positive at the end of the course: students of introductory environmental science courses said that the course changed the way they think, and they are ready to change things in their personal lives/ behavior. According to some students, introductory environmental science courses should be taken by all undergraduate students (as testified by a student email to CM and oral student feedback to AM). PP reports that even the weakest students experience a strong impact. She also points out that whether behavior will change depends on a number of factors, such as investment in the course and additional courses with sustainability component that students may have taken. CM reports that Environmental Studies graduates have repeatedly said that the Environmental Justice course "made an indelible mark on them".

\subsection{Difficulties and Challenges Faced}

Regarding the difficulties and challenges faced when teaching about the environment and sustainability, instructors reported among other the negative student predisposition of some students. Students think they alone cannot change the world. Students even question scientific findings, according to AM; it is difficult to persuade them to use the scientific method and be open-minded, according to PP; and CM says that they accept any piece of information as sufficient evidence for scientific work. Additionally, CM believes that "sustainability is a term that has been abused, making this a shaky and difficult ground to start form". Combatting such negative student attitudes towards scientific findings and student belief that they cannot contribute to change is an obstacle that needs to be overcome.

Factors that may have an impact on attitudes and behaviors include students' prior knowledge and background (educational background, culture, ethnic origin), but also the teaching approach used. So, another challenge instructors face is that students are used to traditional teaching methods where they act as passive recipients of knowledge and sometimes resist to become active learners. All three instructors agree that engagement with course material is important. PP says that once students realize the approach is learner-centered, they quickly adapt. Emotional engagement is also important, as stated before, but "emotional engagement is easier than behavioral change", CM says, while PP believes that "Once emotional engagement is ensured, it is sure that behaviors will change in the long run".

Other challenges mentioned were the breadth vs. depth dilemma: can you cover the content breadth required in introductory courses and in parallel achieve deep knowledge using active learning methods? Time constraints and infrastructure constraints such as technology equipment and training available, the arrangement of learning spaces and numbers of students in each class can also be important limiting factors that may hinder the use of teaching methods that will help achieve the desirable outcomes.

\subsection{Present and Past Student Populations}

The three instructors' long experience in teaching at undergraduate level allowed them to reflect and compare differences among present and past student populations concerning attitudes towards the environment and sustainability. According to AM, 
awareness of environmental issues and readiness for change/action seem to have increased among students of today, with students being more interested and motivated to learn about the environment and their educational and cultural background playing a critical role in this. On the other side, CM stresses that the way students learn has changed. She says that audiovisuals and traditional teaching methods seem to have little impact relative to past times; students are overwhelmed with information from different sources and more "shocking" methods are needed for producing an effect on them. Another challenge pointed out by PP is that students' background on environmental issues and sustainability is superficial and their overall background in sciences is lower than in the past, also indicating that new teaching methods are needed.

\subsection{Most Effective Learning Activities}

All three instructors agree that topics/learning objects that have bigger impact on attitudes and behavior are those that are practical and experiential in nature, related with real life conditions; that involve not just gaining knowledge, but also critical thinking and reflection on action; and that have an impact on emotions; examples include their ecological footprint, extinction of species, water stress or local community problems.

Concerning the most effective learning activities to achieve an impact on attitudes and behaviors, all three instructors agree that active and experiential learning would be the most effective approach. "Activities that render students responsible for their learning", according to CM. Examples of learning activities evaluated positively by AM are field and lab work, audiovisual material (although less effective than in the past) shown and discussed in class, in-class debates, flipped classroom activities, as well as quizzes followed by in-class discussion.

\subsection{Student Feedback on Specific Courses Confirms Instructors' Perceptions}

Student feedback in introductory environmental science courses, obtained through an end-of-semester survey confirms instructors' perceptions. An analysis of this feedback shows that the majority of introductory environmental science students feel that the course influenced their attitudes towards the environment and sustainability. According to their statements, the course helped them better understand sustainability and the human impact on the environment; it provided a base of information; it increased their awareness of environmental issues and taught them how to live more sustainably; students are now ready to reduce waste, recycle more, drive less, eat less meat; they appreciate nature more and can make more environmentally friendly decisions The most effective teaching methods mentioned confirm instructors' perceptions. Some students reported that instructor enthusiasm also matters. According to students, the course activities that had a bigger impact on their emotions and attitudes are: field trip to campus forest/outdoor activities; lab activities; ecological footprint quiz; videos; images, in general; discussion about extinction of species; about climate change; about water issues. It seems that practical/hands-on experiences are more effective in reaching the emotive and generating some mobilization. 


\section{Conclusions - Suggestions}

This study was a reflection of three instructors about the impact of their teaching on student attitudes towards the environment and sustainability, informed by students' feedback. The conclusions that can be drawn provide also good suggestions for instructors who wish to cultivate pro-environmental behaviors. The study shows that content/learning objects of practical and experiential nature, that involve not just gaining knowledge, but also critical thinking and reflection on action, have bigger impact on attitudes and behaviors. It also verifies that a student-centered teaching approach, using active learning methods seems to produce more learning. For attitudinal and behavioral change, experiential methods, with focus or real life situations and local problems, seem particularly effective. Examples of such methods include: lab and field activities; problem solving; case study analysis; student projects and group work, especially addressing real life cases; role playing; debates; in-class and online discussions on specific topics; visuals (see Table 2). Teaching in the environment and activities that produce emotional engagement seem to also have an effect on attitudes. Instructors should teach students to think in an integrative manner and to make connections; and should expose students to real life situations. Exercises that ask students to reflect on their experiences and to draw lessons for life can also have an effect on attitudes.

The use of ICTs tools to facilitate learning and communication is important, but instructors should be aware of related pedagogy issues, so that they use ICTs in the most effective manner. Instructors should try to maximize student engagement with learning activities; the more engaged students are, the better they learn. Teaching methods and learning activities should be selected and designed based on course level, teaching goal and learning outcome; and their implementation should be carefully planned. The effectiveness of teaching methods should be evaluated using performance in assessments and student feedback as criteria. If needed, revisions to the teaching strategy, assessment strategy or course content, should be made.

There are implications and suggestions for higher education institutions as well. Teacher training on active learning and technology-enhanced learning are considered important prerequisites for supporting efforts to cultivate pro-environmental behaviors. Administration training is also important, as administrators are expected to provide the appropriate structures and support to instructors, students and staff. Flexible learning spaces/settings and infrastructure seem to be important for achieving active learning. And collaborations need to be supported.

Table 4: From transmissive to transformative education (revised from Marouli et al., 2018)

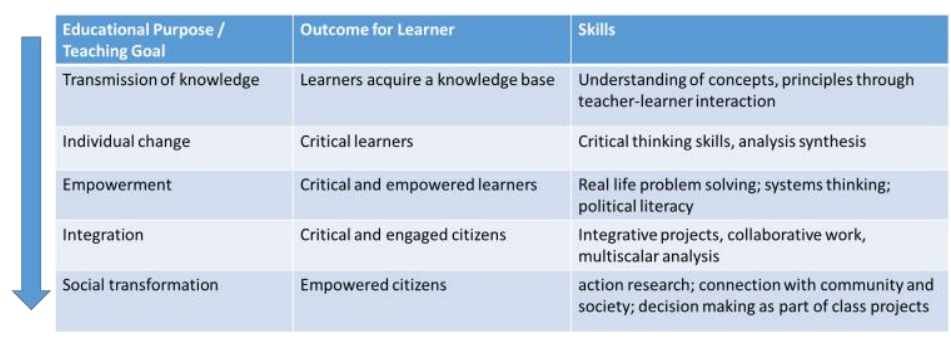


Cultivating pro-environmental attitudes is the first step to transformation towards sustainable societies; it is thus important to make the transition towards a more transformative teaching. Table 4 shows the stages in the transition from a transmissive to a transformative education, the outcomes for the learner and the skills that should be developed in each stage (see also Marouli, Misseyanni, Papadopoulou \& Lytras, 2018; Marouli \& Duroy, 2019). Further studies on student and instructor perceptions will shed more light on which teaching methods are most effective at cultivating proenvironmental attitudes and at creating not just informed learners, but also critical, engaged and empowered citizens.

\section{References}

Bonwell, C. \& Eison, J. (1991). Active learning: Creating excitement in the classroom (ASHE-ERIC Higher Education Report No. 1). Washington, DC: George Washington University.

Breunig, M. (2017). Experientially learning and teaching in a student-directed classroom. Journal of Experiential Education, 1-18.

Cassell, P. (ed.) (1993). The Giddens Reader. London: The MacMillan Press.

Dobson, A. (2007). Environmental citizenship: towards sustainable development. Sustainable Development 15(5), 276-285.

Edgerton, R. (2001). Education White Paper. Retrieved from http://www. pewundergradforum.org/wp1.html.

Eilam, E. \& Trop, T. (2012). Environmental Attitudes and Environmental Behavior-Which is the Horse and Which is the Cart? Sustainability, 4(9), 2210-2246. https://doi.org/10.3390/su4092210.

Hesselink, F., van Kempen, P. P. \& Wals, A. (2000). ESDebate: International On-line Debate on Education for Sustainable Development (Gland, Switzerland: International Union for the Conservation of Nature). Available online at: https://portals.iucn.org/library/sites/library/files/documents/2000034.pdf

Jickling, B., \& Wals, A. E. J. (2008). Globalization and Environmental Education: Looking beyond Sustainable Development. Journal of Curriculum Studies, 40,1-21.

Koehler, M. J. \& Mishra, P. (2009). What is technological pedagogical content knowledge? Contemporary Issues in Technology and Teacher Education, 9(1), 60-70.

Lorenzoni, I., Nicholson-Cole, S. \& Whitmarsh, L. (2007). Barriers Perceived to Engaging with Climate Change among the UK Public and Their Policy Implications. Global Environmental Change, 17 (3-4): 445-459.

Marouli, C. \& Duroy, Q. (2014). The Nexus Between Climate Change and Social Practices: Theoretical and Empirical Reflections for Policymaking. Seton Hall Journal of Diplomacy and International Relations, Fall/Winter, 131-145.

Marouli, C. \& Duroy, Q. (2019). Reflections on the Transformative Power of Environmental Education in Contemporary Societies: Experience from Two College Courses in Greece and the USA. Sustainability, 11(22), 6465. https://doi.org/10.3390/su11226465

Marouli, C. \& Misseyanni, A. (2017). Sharing knowledge in Higher Education: Collaborative teaching, collaborative learning and ICTs. In DisCo 2017: Open education towards a knowledge-based society, 12th Conference Reader; Beseda, J., Rohlikova, L., Bat'ko, J. (Eds.); Center for Higher Education Studies: Prague, Czech Republic, pp. 313-322.

Marouli, C., Misseyanni, A. Papadopoulou, P. \& Lytras, M. (2016a). ICT in Education for Sustainability: Contributions and Challenges. In Proceedings of the International Conference: Future of Education, Florence, Italy, 29 June-2 July 2016, pp.189-193.

Marouli, C. Misseyanni, A., Papadopoulou, P. \& Lytras, M. (2016b) Game-based learning and gamification: Towards the development of a how-to guide in STEM education. ICERI2016 Proceedings, pp. 53435352. doi: 10.21125 /iceri.2016.2299 
Marouli, C., Misseyanni A., Papadopoulou, P. \& Lytras, M. (2018). A New Vision for Higher Education: Lessons from Education for the Environment and Sustainability. In: A. Misseyanni, M. D. Lytras, P. Papadopoulou, C. Marouli (Eds.) Active Learning Strategies in Higher Education (pp. 361-387). UK: Emerald Publishing Limited.

Meyer, C. \& Jones, T.B. (1993). Promoting active learning: Strategies for the college classroom. San Francisco: JosseyBass.

Misseyanni, A. \& Gastardo, M.T. (2017). Active Learning in the Sciences: The Case of an Undergraduate Environmental Science Class. Academic Journal of Science, 07(02), 207-216.

Misseyanni, A. \& Gastardo, M.T., (2019). Students' Perception of Online Tools in the Transition to Blended Learning. In Proceedings of 14th International Conference DisCo 2019: E-learning - Unlocking the Gate to Education around the Globe, Prague, Czech Republic, 20-21 June 2019 (in press).

Misseyanni, A., Papadopoulou, P., Marouli, C. \& Lytras, M.D., (2018). Active learning stories in higher education: Lessons learned and good practices in STEM education. In: A. Misseyanni, M. D. Lytras, P. Papadopoulou , C. Marouli (Eds.) Active Learning Strategies in Higher Education (pp.75 105). UK: Emerald Publishing Limited.

Misseyanni, A., Papadopoulou, P. \& Marouli, C., (2018). Active learning in Higher Education: Instructors' Perspectives and Practices on Pedagogy, Teaching Methods and Assessment. EDULEARN18 Proceedings, pp. 1642-1652. 10.21125/edulearn.2018.0491

Misseyanni, A., Marouli, C., Papadopoulou, P. \& Lytras, M. (2017). Exploring Collaborative Learning as an Active Learning Approach in Higher Education. EDULEARN17 Proceedings, pp. 8041-8050. doi: 10.21125/edulearn.2017.0479

Papadopoulou, P., Marouli, C., Misseyanni, A. \& Lytras, M. (2016). Preface in Special Issue: Teaching in Higher Education: Active Learning, and New Teaching Methodologies. International Journal of Knowledge Society Research (JKSR), 7(4) https://www.igi-global.com/journal/international-journalknowledge-society-research/1180

Papadopoulou, P., Lytras, M., Misseyanni, A. \& Marouli, C. (2017). Revisiting evaluation and assessment in STEM education: A multidimensional model of student active engagement. EDULEARN17 Proceedings, pp. 8025-8033. doi: 10.21125/edulearn.2017.0477

Pizmony-Levy, O. \& Michel, J.O. (2018). Pro-Environmental Attitudes and Behaviors in Higher Education: Investigating the Role of Formal and Informal Factors, Columbia/Academic Commons https://doi.org/10.7916/D85M7J8N

Račinska, I., Barratt, L. \& Marouli, C. (2015). LIFE and Land Stewardship. Current status, challenges and opportunities. Report to the European Commission.

Rosentrater, K. A. \& Burke, B. R. (2017). University Students and Sustainability. Part 1: Attitudes, Perceptions, and Habits, Journal of Sustainability Education 16. Retrieved from https: / lib.dr.iastate.edu/cgi/viewcontent.cgi?article $=1221 \&$ context $=$ engl pubs.

Şahin, H. \& Erkal, S. (2017). An Investigation of University Students' Attitudes Toward Environmental Sustainability. European Journal of Sustainable Development 4, 147-154.

Shaull, R. (1970). Foreword in: Pedagogy of the oppressed (Freire, P.).

Smith, K. A., Sheppard, S. D., Johnson, D. W. and Johnson, R. T. (2005). Pedagogies of engagement: Classroom-based practices, Journal of Engineering Education, 94, 87-101.

Tilbury, D. (1995). Environmental Education for Sustainability: defining the new focus of environmental education in the 1990s. Environmental Education Research. 1(2): 195-212. doi:10.1080/1350462950010206.

Ull, M. A., Martinez-Agut, P., Pinero, A. \& Aznar-Minguet, P. (2014). Perceptions and Attitudes of Students of Teacher-Training Towards Environment and Sustainability, Procedia Social and Behavioral Sciences, 131, 453-457.

UNESCO (1975). The Belgrade Charter: a framework for environmental education. Retrieved from https://unesdoc.unesco.org/ark:/48223/pf0000017772 on 29 November 2019

UNESCO (1977). Intergovernmental Conference on Environmental Education; Final report; UNESCO: Tbilisi. Retrieved from https://unesdoc.unesco.org/ark:/48223/pf0000032763 on 29 November 2019

UNESCO (1992) UN Conference on Environment and Development: Agenda 21. Retrieved from https://sustainabledevelopment.un.org/outcomedocuments/agenda21 on 29 November 2019. 